Secretariat: International Food Policy Research Institute 2033 K Street, N.W. Washington, D.C. 20006 U.S.A.

\title{
Are There Customary Rights to Plants? An Inquiry Among the Baganda (Uganda), with Special Attention to Gender
}

\author{
Patricia L. Howard and Gorettie Nabanoga
}

2033 K Street, NW, Washington, DC 20006-1002 USA • Tel.: +1-202-862-5600 • Fax: +1-202-467-4439 ifpri@cgiar.org www.ifpri.org

NOTICE: CAPRi Working Papers contain preliminary material and research results, and are circulated prior to a full peer review in order to stimulate discussion and critical comment. It is expected that most CAPRi Working Papers will eventually be published in some other form, and that their content may also be revised.

Copyright 2005, International Food Policy Research Institute. All rights reserved. Sections of this material may be reproduced for personal and not-for-profit use without the express written permission of but with acknowledgment to IFPRI. To reproduce the material contained herein for profit or commercial use requires express written permission. To obtain permission, contact the Communications Division at ifpri-copyright@cgiar.org 


\begin{abstract}
Debates around Common Property Resources and Intellectual Property Rights fail to consider traditional and indigenous rights regimes that regulate plant resource exploitation, establish bundles of powers and obligations for heterogeneous groups of users, and create differential entitlements to benefits that are related to social structures. Such rights regimes are important to maintaining biodiversity and to human welfare; failing to recognize them presents dangers. The case study investigates the gendered nature of informal rights to selected tree and plant species that are distinct from, but related to, customary rights to land and trees, and are embedded in cosmology and social norms.
\end{abstract}

Key words: Common Property Resources, Intellectual Property Rights, plant resources, gender, Africa, Uganda 


\section{Table of Contents}

1. Introduction 1

2. Conceptualizing Plant Rights Regimes 5

3. Gender and Rights to Plants 15

4. Methods and Context 17

5. Species Results 22

6. Conclusions $\quad 42$

$\begin{array}{ll}\text { References } & 47\end{array}$ 


\title{
Are There Customary Rights to Plants? An Inquiry Among the Baganda (Uganda), with Special Attention to Gender
}

\author{
Patricia L. Howard ${ }^{1}$ and Gorettie Nabanoga ${ }^{2}$
}

\section{INTRODUCTION}

Plant resources, besides being the ultimate origin of all food, provide the material basis for the livelihoods of billions of traditional and indigenous peoples across the planet $^{3}$ as the principle raw materials for food, medicine, construction, textiles, fuels, utensils, crafts, cosmetics, chemicals, religious and ritualistic artifacts, and other products that fulfill most human needs. Between all of these applications, a single traditional or indigenous community often purposefully exploits many hundreds of plant species. While plants are, in theory, renewable resources, in the absence of particular ecological conditions that help maintain plant population densities and of social control systems that protect and manage important plant ecosystems and species, they can be definitively lost, both locally and globally - indeed, plant species are disappearing at an alarming rate across the globe (Millennium Ecosystem Assessment 2005). In spite of the fact that efforts are now being made to reverse this trend, there have still been relatively few

\footnotetext{
${ }^{1}$ Corresponding Author: Prof. Patricia Howard, Dept. of Social Sciences, Wageningen University, P.O. Box 8130, 6700 EW Wageningen, Netherlands, Phone. +31-317-420773, Fax. +31-317-840416, Email: Patricia.Howard@wur.nl

${ }^{2}$ Gorettie Nabanoga, Faculty of Forestry and Nature Conservation, Dept. of Community Forestry and Extension, Makerere University, P. O. Box 7062, Kampala, Uganda

${ }^{3}$ There is apparently no current global estimate of the number of hectares or people who depend upon traditional agroecosystems for their livelihoods. A few indicators serve as poor substitutes, e.g. the number of farmers using no tractors or animal traction power, improved seed, fertilizers or pesticides, which FAO has estimated at one billion (FAO 2004), to which should be added the number that have access to animal traction and that use a minimal amount of external inputs, which should at least double this figure.
} 
attempts to document, analyze or conceptualize customary social control systems, or "rights" to plants.

Neglect of customary "rights" to plants appears to originate from the assumption that plant "ownership" is automatically derived from land tenure - private landholders ipso facto hold exclusive rights to plants growing or produced on their land, and plants growing upon land that is commonly held are also common property. These assumptions obscure the fact that rights to plants are often quite different from rights to land, and socalled "common property" in plant resources is in fact often not "common" (Cleveland and Murray 1997; Howe and Sherzer 1975; Mgbeoji 2002; Oguamanam 2003). Rights to plants, we argue, are no different in this sense from rights to other important natural resources such as marine life and water, where for some decades it has been recognized that customary rights regimes around these resources are highly complex and dynamic; that they exist apart from, although interrelated with, rights to land or territories; and that they establish "bundles of powers" for heterogeneous groups of users and knowledge holders within cultures, which also create differential entitlements to the benefits of their use (see e.g. Acharya 1990; Bruce and Fortmann 1988; Conklin 1954; IWMI et al. 2005; Kundhlande and Luckert 1998; Nugent 1993; Robbins 1996; Sheridan 2001). We argue that rights to plants are generally uncodified, ubiquitous, and constitute an integral part of power relations; are embedded within cultural systems and regulated by customary institutions and norms; are both consciously and unconsciously respected, contested and negotiated; and are adaptive and dynamic.

The relevance of customary rights regimes around plants cannot be overstressed. Over the past decade or so, nearly across the globe, there has been a strong resurgence of 
policy and academic debates around customary tenure. Two major drivers are involved. The first is the concern with environmental degradation and sustainable resource use that leads to a focus on common property resources (CPR) and especially on the question of whether CPR regimes are more or less effective for sustainably managing natural resources while alleviating poverty. But CPR discussions have generally ignored indigenous and traditional people's rights to plants, so that these institutional dimensions of plant biodiversity conservation and loss have gone largely unexplored. The second driver is the debate around Intellectual Property Rights (IPR) and particularly the concern with developing rights regimes that can protect traditional and indigenous people's knowledge, practices and benefits. The focus of most discussion on IPR is on plant genetic resources, so that it could be expected that these debates would be concerned with actually-existing traditional or indigenous rights regimes around plants. But IPR debates also generally fail to acknowledge the existence, complexity and dynamics of such CPR regimes in relation to plants, and rather reflect the assumption that plant resources are "commonly held" by traditional and indigenous groups. The pre-existence of complex systems of rights to plant resources within these groups goes unrecognized.

While we do not address whether or which IPR regimes may be desirable to protect traditional or indigenous peoples' rights to plants, we argue that there are very substantial dangers to the failure to recognize existing customary rights systems. Customary plant rights are a major institutional component for achieving the sustainable use and management of biological diversity and the equitable distribution of the benefits from such use, which are objectives of the Convention on Biological Diversity (CBD Secretariat 1992). Customary natural resource rights regimes have often helped to ensure 
sustainable management of both resources and their respective landscapes over the long term, as well as a distribution of resources that helps to ensure that all members of a society are able to meet subsistence needs (Grigsby 2002; Peluso 1996; Scott 1976). Customary rights to plants are likely to be subject to the same types of pressures and dynamics that are affecting other CPR regimes such as changing formal tenure, establishment of restricted areas for purposes of conservation, commoditization and expropriation of resources and land, development interventions, racism, increased social differentiation, migration, and population growth (Aggarwal 2001; Calamia 2003; Chapeskie 1993; Malm 1999; McDermott 2000; O’Flaherty 1997; Olson 1995; Peluso 1996; Sheridan 2001; Wagner 2002). Plants are not only major subsistence resources: knowledge about them, and their use and control, also confer status, wealth, power, and meaning, and are thus intimately related to both cultural and material integrity and wellbeing (Howard 2003; Peluso 1996). Just as has occurred in the case of customary land tenure, the failure of "outsiders" to acknowledge customary rights around plants can have serious implications for traditional management and knowledge systems and their sustainability, as well as for cultural integrity and welfare (Dove 1997).

This study focuses, then, on the nature and dynamics of indigenous or traditional rights regimes around plants. ${ }^{4}$ First we present a conceptual framework that has the virtue of being concrete enough to operationalize for the purposes of research. In part, it departs

\footnotetext{
${ }^{4}$ Such customary rights may be formal or informal - in the case explored here, customary land rights are formal and codified, whereas customary plant rights are generally informal and uncodified, and may be seen to complement and complicate formal customary rights. It is also possible that they come in conflict with such rights, but no evidence of that was found in the case study. Further, there is no reason to think that customary rights to plants are only features of traditional or indigeneous populations - there is every reason to suppose that they are pervasive across all societies (see e.g. various chapters in Bruce and Fortmann 1988).
} 
from frameworks developed to conceptualize "tree tenure." With very few exceptions, the concern with trees has not led to empirical or theoretical work on "plant tenure" more generally, so that there is a lack of knowledge of such broader rights systems, and we also cannot determine whether trees represent a special case (e.g., because of their longevity) in comparison to other types of plant resources. ${ }^{5}$ We also draw upon a conceptual framework from cognitive anthropology for understanding the distribution of plant knowledge in traditional and indigenous societies, as well as much empirical research on gendered rights to trees and plants. The case study we present focuses especially on the gendered nature of such systems among the Buganda in Central Uganda. To explore these relations, we review customary and formal land and tree tenure and then focus on gendered uses and rights pertaining to specific resource areas in which four species are found that are culturally and economically important to the Buganda: Fig - Ficus natalensis, Jackfruit - Artocarpus heterophyllus, Palm - Phoenix reclinata and Cat's whiskers - Cleome gynandra. Three are trees and one is a wild plant species, which permits us to begin to determine whether there are differences in rights between tree and non-tree species.

\section{CONCEPTUALIZING PLANT RIGHTS REGIMES}

There is first of all a question as to whether social relations around access to and control over plant resources constitute "property rights," or whether they are better

\footnotetext{
${ }^{5}$ Seed probably also present another "special case" of plant rights given their specific characteristics and purposes (Cleveland and Murray 1997; Eyzaguirre and Dennis, this volume; Howard 2003).
} 
conceived of as what feminists and others often refer to as "relations of access and control.” Referring to Ribot and Peluso’s (2003) conceptual work comparing property rights and relations of access and control, we assert that such relations are best understood as property rights regimes, since they extend beyond the "ability to benefit from things" and rather constitute "socially acknowledged and supported claims or rights" associated with things (Ribot and Peluso 2003: 154-155). A major problem for Western scholars is to understand or characterize emic concepts underpinning such social relations, as well as the mechanisms through which such rights are defined and sanctioned, since religious, ritualistic, and normative beliefs and traditions often constitute the principle basis of legitimacy for such social relations. Traditional and indigenous peoples may or may not have concepts of property rights per se, but apparently all do recognize what Ellen (1993 1998) refers to as "morals" that are invoked to regulate access to natural resources found in various landscapes, although these may or may not be formalized in customary or formal legal codes. Spiritual or social "morals" represent foundations of, and mechanisms to reproduce, intra-community and intrahousehold property relations, of which gender relations are an intrinsic feature.

A point of departure for examining rights to plants more generally is the concept of "tree tenure" (Bruce and Fortmann 1988; Fortmann and Bruce 1988). It is conceived of as the rights to own, bequeath, plant, use and dispose of a tree or tree part, where an individual's rights to trees may depend on their rights to the land upon which the tree is growing, or where land rights may be established by planting trees. Tree tenure consists of a distinguishable bundle of rights that may be held by different people at different times, where rights are dependent on factors such as tree species, ownership, location, 
land ownership in that location, whether the tree was planted or grew naturally, and the division of labor in tree management and use, or in the management and use of tree parts (Fortmann and Bruce 1988). In turn, these may be related to cultural or spiritual beliefs that prescribe or proscribe activities and resources to certain groups. The multiplicity of uses to which a tree or tree product may be put and the degree to which different uses are in conflict (e.g., for timber versus fuelwood) also influence rights. All of these rights may or may not be held by one and the same person or group, but four categories of rights holders are often involved that may exercise rights simultaneously and in different ways: the State, social groups, households, and individuals within households (Bruce and Fortmann 1988).

We put forth a more general framework for analyzing plant rights regimes that is further meant to capture how the sets of rights and obligations may correspond to social structures, that is, how access to "bundles of powers and obligations" are distributed among groups and even among individuals. We argue that the allocation of rights to plants bears a relation to the distribution of plant knowledge within traditional and indigenous communities, where both are determined by the importance of particular plants to particular people within them. James Boster (1985), a renowned cognitive anthropologist, examined the distribution of ethnobiological knowledge among the Aguaruna in the Peruvian Amazon, and found that it reflects Aguaruna social structure. A corpus of knowledge (a "cultural cognitive model") exists in relation to phenomena such as plant and bird names and identification, and agreement about these phenomena "is patterned in the way that one would expect such knowledge to be patterned ... 
[where] variation between informants can be explained by factors that reflect differential knowledge: age, sex roles, and opportunities to learn" (1986, pp. 185). He argued that An individual can be considered as having a number of identities: a member of a society, an actor in a sex role in that society, a member of a household, and an individual. Different amounts of knowledge are shared at each of these layers. A certain amount can be presumed of any adult member of the society. That and more can be assumed as an actor in a sex role. Still more is shared between closely related people. Finally, certain knowledge is unique to the individual. As the difficulty or specialization of an identification task increases, agreement at all of the layers decreases but not at equal rates. Sharing at the most general layers falls off most quickly. Thus there is an apparent succession in the importance of these layers of identity depending on the difficulty of the task (Boster 1986: 191).

We posit that access and knowledge are both generally prerequisites of traditional plant use, and that rights to plants also reflect social structure, which in turn "determines the importance of particular [resources] ... to particular people within it" (Boster 1986). In traditional communities, the most commonly used plant resources are likely also to be those where access rights and obligations extend to all members of a community, or where the obligation to produce such plants is pervasive. Gender is one of the major factors influencing rights to plants - being a woman implies sharing certain rights and obligations with other women, but not necessarily with men. Then, women in a particular household or kin network will be more likely to share rights to particular plants. However, the analogy is only useful up to this point - unlike knowledge, plants are physically tied to land, and different plant resources have different biological 
characteristics that create quite different sets of conditions around access and use. For example, certain uses of plants will destroy them whereas others won't, and right regimes may proscribe uses that destroy plants, or stipulate that plants be managed in such a way as to stimulate reproduction or production of particular parts, such as fruit. ${ }^{6}$ The occurrence of particular species only in a particular biotope may lead to the creation of rules applicable only to that species that may be quite different from rights regimes that apply to this biotope more generally.

The hypothesis pursued in this research is that plant rights regimes will tend to reflect the following parameters:

Part $\mathrm{Z}$ of species $\mathrm{A}$ in resource area $\mathrm{X}$ can be used by person $\mathrm{Y}$ if the use is for $\mathrm{B}$ and $\mathrm{Y}$ abides by rule $\mathrm{M}$, during season $\mathrm{C}$

Within this complexity, patterns are expected to emerge in relation to:

- Resource areas (variable $\mathrm{X}$ ) since this is also governed by land tenure (de facto and de jure; customary and formal);

- Trees (a subset of variable A - tree tenure and in particular tree ownership),

- Particular uses (variable B - e.g. for medicine, for consumption on the spot, for household subsistence, for sale);

- Groups of persons (variable Y - e.g. children, herbalists, poor women, cattle owners)

\footnotetext{
${ }^{6}$ For more extensive discussions, see Peluso 1996; Pfeiffer and Butz 2005.
} 
- Particular periods or seasons (variable C - e.g. when species become available; when competition with livestock does not occur; during religious holidays)

- Harvesting limits or management practices (variable $\mathrm{M}$ ), which are also associated with the species, the resource area, the uses and the persons involved (e.g. the requirement to use a digging stick to cultivate roots at the same time that a wild species is being harvested; to not uproot plantlets).

The formula incorporates the relation between rights and social identities insofar as it requires the specification of "person Y," and one way in which the so-called "bundles of powers and obligations" become visible is by analyzing the patterns that emerge from the application of the formula across persons, resource areas, species, variable time periods and uses, revealing which sets of interactions are related to which social identities.

The patterns that can be expected to emerge are not arbitrary, but rather are associated both with fundamental organizing principles within local populations and with historical cultural, economic and ecological change. Howe and Sherzer (1975) showed how such a system of rights to plants is culturally, rather than juridically encoded in the way one population classifies the plant world. They studied the San Blas Cuna Indians, a population of about 25000 agriculturalists inhabiting the northeast coastal area of Panama, where each household cultivates numerous swidden fields dispersed throughout the landscape. People are unable at all times to monitor their holdings, so that theft, or the threat of theft, is an intrinsic feature of their life-world. On the other hand, as is the case with many subsistence-oriented societies, the San Blas Cuna also "have a strong and very self-conscious ethic of generosity, one in which food-sharing plays a central role" (Howe 
and Sherzer 1975, p. 438). The authors posited that, given these conditions, there must be "a set of shared understandings concerning access to things growing on farms" and interviewed informants to unearth such patterns. They discovered "more or less identical set of criteria that characterize and differentiate into access-sets the products of every kind of plant or tree in the forest, wild or cultivated" (Howe and Sherzer 1975). One semantic term first classifies plants into the categories "have an owner" (ipet nikka) or "belong to God" (tios kati); a sub-category distinguishes products that can be obtained as a gift from the owner and those that cannot (where coconuts can only be obtained from a parent); and another distinguishes what must be asked for "in advance" versus what can be taken without prior permission, and so forth. It is worthwhile reproducing the authors' summary of the San Blas Cuna classification system here. 
Figure 1-- Cuna crop classification
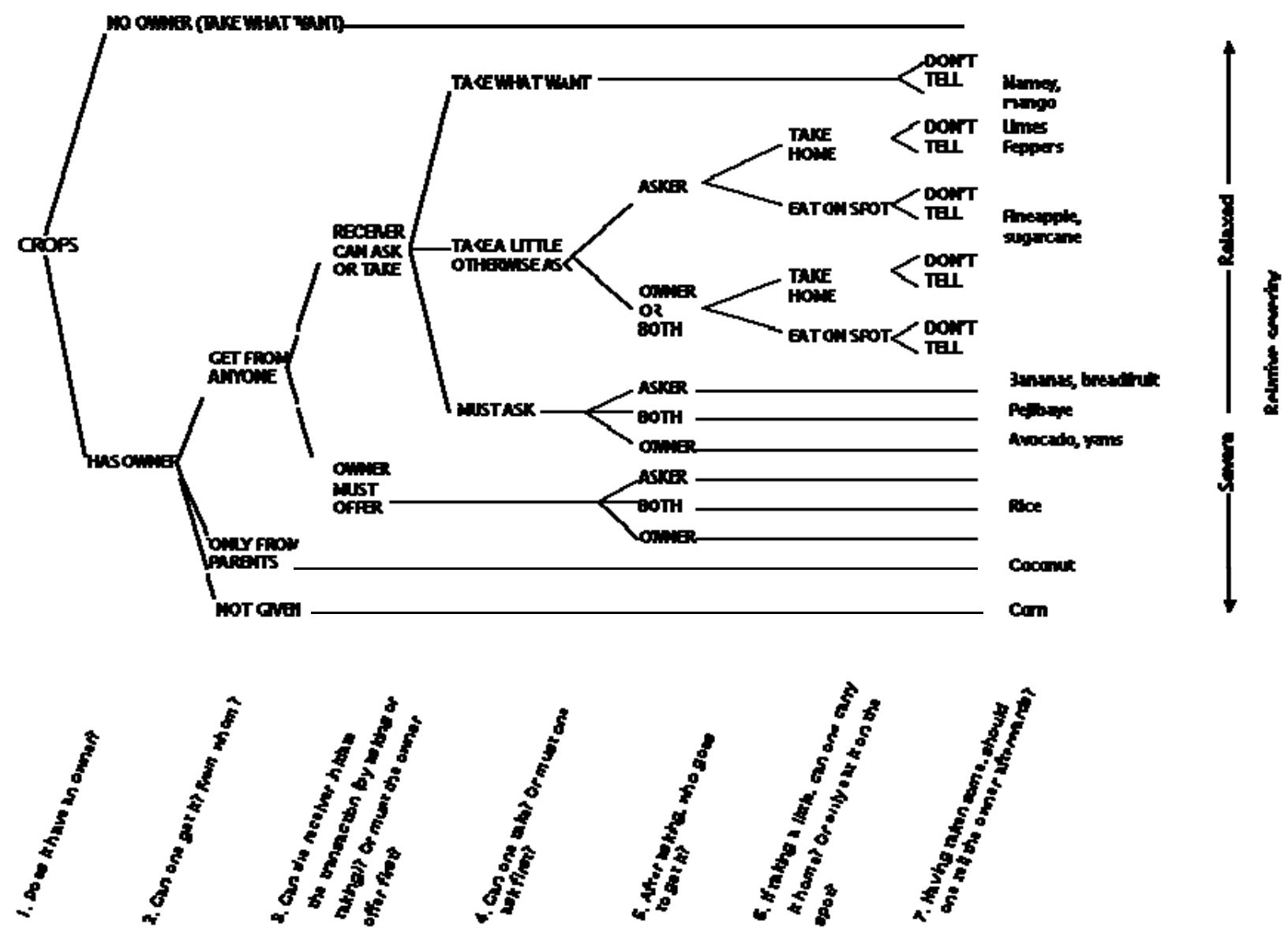

Source alpipled fiom Hone and Shareer, 1975

Irrespective of whether such a taxonomically embedded system represents a veritable rarity or only a rare encounter (since researchers often do not find what they $a$ priori assume does not exist), and of irrespective of whether they are indeed important or not to actual behavior (Ellen 1982: 209), the principle that they put forth cannot be obviated - shared sets of understandings about plant access must exist and must be socially encoded. 
As we have argued, an additional dimension of such 'shared understandings' or property rights regimes is that they are embedded in "bundles of powers" (Ghani 1995; cited in Ribot and Peluso 2003) where power relations, such as gender power relations, underlie these rights. Rights or powers are associated with duties or "bundles of obligations" - which extend beyond the obligations of individuals to be generous or not to steal - and which are embedded in social, behavioral and cosmological norms about social roles that form the basis for and legitimate customary rights regimes around plants, as much anthropological research has shown - e.g., men may be vested with the obligation to be generous and to exchange resources such as food within the community, whereas women, but not men, may have the obligation to produce the crops that men exchange (e.g. Sillitoe 2003).

A final essential caveat with regard to the patterns that are likely to emerge from the application of such a formula is that, like power relations, customary property rights are far from static or 'tradition-bound'. As a social institution, property consists of "constellations of social interactions, in which people move, acquire and exchange ideas and resources, and negotiate or contest the terms of production, authority and obligation" (Berry 1997, p. 1228). Therefore, as Berry further argued, property is best viewed as a process rather than "sets of fixed rules." Again, the case of the San Blas Cuna is illustrative. As cash crops were incorporated into their subsistence economy, thus creating contradictions with traditional ethics and mechanisms that ensured generosity and reciprocity, plant rights were adapted, so today the Cuna differentiate crops according to whether and to what extent the compulsion to give applies, thus leaving people free to be generous with some things, and ungenerous with others, especially cash 
crops... [the system is] neither static nor timeless. It relates to history not merely as a worn-out residue, a combination of bits and pieces from the past. Rather, it reflects both the situation in which the Cuna now find themselves and the dominant social and economic changes they have undergone in the last century, and we cannot fully understand the classification without taking these processes into account (Howe and Sherzer 1975, p. 443).

If such systems were not dynamic, they would rapidly become dysfunctional, out of sync with environmental and economic realities and with shifting power configurations internal and external to communities. Permutations are also intrinsic. First, at any given moment, differences exist between prescriptions and effective behavior and sanctions - some rules are enforced more severely than others, and some people 'get away' with things while others do not. The process of 'making rights real' depends upon power relations and the capacity to legitimate claims by reconfiguring or creating stereotypes, including by creating or re-creating 'tradition' or 'custom'. Thus, "actors deliberately create new norms to achieve different goals" using a plurality of norms and rights regimes that co-exist in order to claim legitimacy (Roquas 2002). And, secondly, customary rights systems are ambiguous, as Howe and Sherzer also noted when analyzing the San Blas Cuna system: “each person's versions of the rules is not only idiosyncratic in some respects but also variable. Ambiguity may be a basic facet of the system, even on the individual level" (1975, p. 454). Room for maneuver is always present in such ambiguities. 


\section{GENDER AND RIGHTS TO PLANTS}

It is well documented that property rights regimes are nearly universally differentiated according to sex. There is more than ample literature that attests to this in relation to tree tenure (e.g. Biggelaar 1995; Fortmann and Rocheleau 1985; Fortmann et al. 1997; Peluso 1996; Quisumbing et al. 2001; Warner 1993). The few studies that discuss traditional rights to plants show that these present no exception. For example, Telfairia occidentalis is a fluted pumpkin consumed as a relish or soup ingredient among 30-35 million Igbos in Nigeria. Women are culturally obliged to produce or procure it for their households - they cannot cut (kill) Telfairia plants belonging to others since to do so desecrates the other's field and, to atone, the earth goddess must be appeased. ". . a woman who harvests Telfairia from the farm of an absent neighbor without permission has done a great evil. . It is considered a serious affair. . After proper sacrifices, they pray: 'let us not again witness more of such acts in our lifetimes"' (Akoroda 1990, p. 37).

Such gendered rights are not confined to domesticated plants, as historical research from the North American continent attests: rights to wild plant harvesting grounds and territories were heritable and passed down from mother to daughter; violations of others' territories were punishable (Compton 1993; Norton 1985; Dick Bissonette 2003). Price's research (2003) in Northeast Thailand focused on a contemporary gendered system of gathering rights to wild plant foods. Rights to harvest wild plants for domestic consumption carry different restrictions than rights to harvest for sale, but these rights also depend upon the specific species and women's perceptions of 
their market value, taste and rarity. Rights to collect these plants on other women's land are linked to matrilocal residence and inheritance, as well as female kinship networks.

The simplest explanation for the gendered nature of plant rights is that there is a gender division of labor, and rights are associated with each sex's distinct obligations to provide goods and services. But the gender division of labor is itself rooted in religious and other social belief systems in which concepts of masculinity and femininity, and norms about behavior that is appropriate for each sex, are intrinsic. These norms prescribe not only the type of activities and responsibilities that are appropriate for men and women, but as well as with whom men and women of different social positions can interact, and in which physical spaces and environments they may carry out activities or socially interact. Much research on land and tree rights shows that men and women may have different access to the same resource areas and also access different spaces. This is in part related to cultural restrictions on women's mobility, which may be considerably less than men's, and to cultural beliefs that, for example, may limit women's access to particular resource areas such as high forests or sacred groves. Seclusion due to religious beliefs may confine women to 'private' spaces and areas near the home, and ideas about female impurity may prohibit women from accessing certain agricultural fields. Only women may be permitted to enter particular spaces, such as homegardens, also for spiritual reasons. Topographical and altitudinal variations in access are also noted, as is access to different types of forests due to beliefs about spirits or other threats to women's security, e.g. from rape (Descola 1994; Goebel 2003; Rocheleau 1988; Pfeiffer and Butz 2005). The gender division of labor therefore may have little to do with norms regarding the tasks that women should or should not carry out, but rather from the association of the 
activity exclusively with a space that women are proscribed from using or expected to use.

Similarly, just as there are "gendered spaces," there are also "gendered species" or “women’s crops” and “men’s crops” (see e.g. Leach 1992; Pottier 1999; Quisumbing 1995; Sillitoe 2003; Padmanabhan, forthcoming) that are commonly associated with each sex's obligations to provide certain subsistence products, but that may also be associated with other gendered cultural constructs, for example that certain crops are "feminine" or "masculine" by nature and are classified as such linguistically (Sillitoe 2003). Further, it may not be plant species per se, but rather particular plant products such as timber, fuelwood, fruit, fodder, and craft materials that are associated with a specific sex, which influences rights to plants and to the spaces where these grow. Particular spaces (e.g. homegardens, swamp lands) may be more strongly associated with particular species and hence are mainly frequented by the respective sex. As Padmanabhan (forthcoming) argues, plants are everywhere "vehicles transporting social significance," and the negotiation of rights to them is at the same time negotiation about men and women's positions in a gendered life-world.

\section{METHODS AND CONTEXT}

Two villages were selected for the research, one within the Buttobuvuma Forest Reserve and the other within the Mabira Forest Reserve, both of which are in central Uganda in Mpigi and Mukono districts, respectively. Both fall within the same agroecological and cultural zone in the coffee-banana belt inhabited by the Ganda tribe 
pertaining to the Buganda kingdom. Population density is high, as is pressure on forested landscapes. Sanga village (pop. 610) is a forest enclave in the Mabira Forest, and Kisamula/Malube is a village (pop. 1300) that surrounds the Buttobuvuma Forest Reserve. Fieldwork took place during 2002 and 2003. Transect walks and participatory mapping served to locate and quantify the species resources within the community. Sexsegregated focus group discussions were held, each with an average of 13 individuals who were considered to be most knowledgeable about each of the species. These were complemented by in-depth, open-ended interviews with men and women species users from five households for each species, thus a total of 40 individuals were interviewed from 20 households. A demographic and socio-economic survey was also carried out for each household. In total, nine men and eleven women were involved in the case study of Ficus natalensis; five women and seven men in the Artocarpus heterophyllus case study; eleven women and eight men for Phoenix reclinata and eight women and three men for the Cleome gynandra study.

The most important forms of land tenure in Buganda include State ownership and customary and mailo tenure. State-owned land is predominantly in forest reserves. Customary land rights are recognized by the State and are determined by the rules of the tribe or clan. Lastly, mailo land, which predominates in the study region, is a form of freehold tenure created by British colonialists which allocated land in perpetuity mainly to tribal chiefs. Subsequent laws ensured that peasants hold rights to most mailo land. Since mailo parcels are too large for owners to cultivate, mailo owners have to rent much of their land to peasant tenants, thus permitting the majority of male peasants to access land (as kibanja). The kibanja holder can transfer his rights to land to a third person and it 
can be inherited, if the landlord has given his consent (Gombya-Ssembajjwe and Banana 1998; Sebina-Zziwa 1998). After 1900, a land market developed in Buganda, where more prosperous Baganda purchased land from mailo landlords. However, in areas where land markets did not develop, most land is still held in customary tenure. In the study area, most falls under mailo tenure or is owned by the State as gazetted forest land, while a smaller area is communally held.

The Bugandan land tenure system privileges men who mainly hold legal land titles and decide the fate of the family estate (Nagujja 1993; Roscoe 1965; Sebina-Zziwa 1998). Women's land access is restricted to usufruct rights under customary tenure: inheritance customs dictate that a man leaving no male offspring is succeeded by one of his male clan relatives. Baganda descent is patrilineal, which favors male over female siblings. Women marry outside of their father's clan and join their husbands' natal homes, thus becoming part of their husband's lineage. Mukwaya noted the temporary nature of women's usufruct rights: “. . . a wife has the right to live on a land holding on the same terms as the husband so long as the husband is still alive and has not surrendered his interests in the holding ... the rights of the wife however lapse on the death of her husband in which case the rights pass to the legal or customary heir" (1953, p. 58). However, it is now not uncommon for male land holders to bequeath land to their female relatives, especially if they have no male offspring. Also, women can purchase land, but very few do so. In the study villages, the only women landowners are widows who act as custodians for the land of their minor sons.

Tree tenure in Buganda is related to these land tenure regimes. In 1987, a new forest policy was promulgated which zoned State forest reserves into three areas: strict 
nature reserve ( 20 percent) in which all extractive human activities are prohibited, a buffer zone (30 percent) where only strictly controlled extraction of non-timber forest products by local women is permitted for subsistence purposes and, in the remaining 50 percent, concessions for timber can be permitted on a sustained yield basis. Further, many of the economic and high value tree species are reserved species that may only be cut with Forest Department permission, even when such trees are located on private land.

In Uganda in general, men dominate tree planting since they are the landowners and, as is the case over much of Sub-Saharan Africa, tree planting increases the security of land tenure. Men therefore take part in deciding where and which trees women plant (Gombya-Ssembajjwe and Banana 1998). Often, women plant trees for fruit and firewood while men plant economically important tree species, but then men must determine in which spaces women plant trees. Together with losing rights to their deceased husbands' land, it is reported that widows lose rights to crops and trees on the land (Mukwaya 1953; Sebina-Zziwa 1998). According to Mukwaya, "The husband is customarily the proprietor of all trees and crops cultivated by his wife, and if the husband leaves, all the crops revert to the land owner" $(1953$, p. 58). There is no substantial difference reported for Buganda or for the study areas. As shall be seen, "proprietor" in this instance does not mean the exercise of exclusive rights.

To understand the social context within which gendered rights to trees and land are embedded among the Baganda, it is important to discuss the sex and age-based division of social obligations and of labor. Male responsibilities traditionally included bark cloth making, fence and house construction, staple crop producion and livestock herding, as well as providing cash to supplement subsistence production (Roscoe 1965; 
Ray 1977). A woman's principal duties were to cultivate her garden and cook the food that she produced. Women and girls were also responsible for collecting water and firewood. Wives also helped to prepare building materials by cutting and cleaning the reeds used in hut construction, and cutting grass for thatching. It was also a major responsibilty for women to weed men's fields. Women's "leisure" time was spent in basket- and mat-making. Although these norms are still largely prevalent today, they have been weakened by formal education, markets and male outmigration, so that women now perform tasks that were traditionally men's or children's. Women are increasingly involved in income-generating activities even when people think that this is degrading for men who are seen as unable to support their households.

Villagers distinguish four main land-use types. Homegardens consist of multicropped, multistory land-use areas closest to the homesteads that are dominated by banana (the main staple crop) and coffee (a major cash crop) which together form the middle storey. Yams, legumes and vegetables form the understory and a variety of trees form the upper canopy. Crop lands are usually contiguous with the homegarden and contain a variety of staple crops such as beans, sweet potato, maize and cassava. When creating these fields, men selectively remove trees, leaving only a few that are beneficial to the crops. Common land refers to customary community land (including sacred groves) and land not rented out or cultivated by mailo owners. These are usually covered by a combination of overgrown herbaceous plants, shrubs and scattered trees. 


\section{SPECIES RESULTS}

The discussion of land and tree tenure in Buganda presented thus far would lead one to conclude that women's rights to land and to trees and other wild and domesticated plants growing thereon are entirely dependent upon their husbands and upon State largess, except when women are landowners. It is by applying the formula developed to analyze plant rights to specific culturally and economically important species that this and the other propositions put forth in this paper may be critically examined.

\section{FICUS NATALENSIS (FIG TREE) (OMUTUBA).}

The fig tree is one of the most important multipurpose trees in Buganda and is one of the principal cultural pillars of the Baganda clans. Its most important cultural use is for bark cloth. It grows in wet and dry forests and thickets, and in riverside and ground water forests in higher rainfall woodlands and savannas, and is often purposefully planted among banana and coffee stands both to produce bark cloth and provide environmental services (Kabuye 1999; Katende et al. 1995).

Bark cloth is used by all Baganda. Historically it was used to pay taxes to the chiefs as well as bridal dowries, which still occurs in traditional marriage ceremonies. It was the principle clothing textile, but today is only widely used for traditional ceremonies, including the King's coronation. Last respects are paid to the dead through gifts of bark cloth, and almost all corpses are covered with it before burial. Twins are wrapped in it after birth for protection. Women commonly use bark cloth to make wall decorations, place and floor mats, handbags, hats, and bedding. Therefore, figs still have great cultural significance as well as economic importance in the study region. 
Spiritual beliefs are related to figs in other ways that affect use. People believe that figs have supernatural powers to mediate between them and their ancestors - for example, they host ancestral spirits that promote women's fertility. Spirits that arbitrate conflicts reside in certain figs and therefore people have a specific tree under which they sit to deal with conflicts. It is mainly the non-Baganda who use figs for firewood: burning figs is taboo for the Baganda since they provide a habitat for clan spirits. However, due to fuel scarcity, some Baganda use figs for fuelwood, which may indicate that beliefs are eroding in part due to resource scarcity.

Figs have many other uses, several of which are environmental. Villagers believe that leaves that fall from figs improve soils. They provide shade for crops such as coffee and banana and are used to support climbing plants such as passion fruit, yams and vanilla. Fig leaves are used to treat stomach ache and the early morning dew that drops from fig leaves is believed to cure coughs. Leaves of young figs leaves are fed to goats. Live fences made from figs demarcate plot boundaries and prevent humans and animals from trespassing. Figs are also used to hang beehives.

Each individual was asked to report his or her uses of figs, responses were compiled, and the frequencies for each use were calculated by sex of the respondent. The predominant uses are for bark cloth making (25 percent of total uses), soil improvement and shade (15 percent each), and support and sacred or spiritual uses (10 percent each) (Nabanoga 2005). Only men use figs to produce bark cloth (it is taboo for women to do this). Most men reported that they sell the bark to bark cloth makers - only two elderly men were found who make bark cloth in the study villages. Women make several types of bark cloth crafts for home use and for sale. Only men use figs to hang beehives and 
create boundaries, whereas only women use figs for soil improvement and as shade for other crops. Both men and women use figs to support other crops; however, women support subsistence food crops (mainly yams) while men support income-generating crops such as passion fruit and vanilla.

The proportion of uses reported per resource area was compared with the distribution of figs in the different resource areas. Figs were found mainly in homegardens (59 percent) and scattered across crop lands (28 percent) and on common land (13 percent). The use/harvest pattern closely conforms to the distribution pattern of the trees in the different resource areas where, overall, more uses were reported in homegardens than in crop and common lands. However, there were a few exceptions: bark harvesting occurred most in crop lands which is also where figs were used to hang beehives. Spiritual uses were highest in common lands which had the lowest number of figs, but these figs are mainly found in sacred groves which are never used for fuel; neither are women allowed to harvest leaves or fruit from them. Women are not allowed to enter sacred groves except on the occasion of traditional or religious ceremonies that specifically involve them, and only then in the company of a male relative, because women are considered to be unclean, especially during menses.

The results were further analyzed to investigate the extent of difference in resource area use by sex. ${ }^{7}$ A greater percentage of the total number of reported uses of figs found in crop lands were made by men (75 percent), while those uses reported of figs located in homegardens were predominantly women's (78 percent). Women also reported

\footnotetext{
${ }^{7}$ The total number of uses equals the number of people reporting a specific use in a particular landscape. The figures reported reflect: of the total number of uses reported for a particular landscape, the percentage of these uses reported by men and by women, respectively.
} 
more uses of figs in common lands (67 percent) than men (33 percent). However, informal discussions with men indicated that most men use figs in sacred groves for various traditional practices, but are reluctant to speak about them. The conclusion is that both men and women use figs on common land, but for different purposes, which also holds for figs located in the other resource areas. Even where the locations and uses are similar for both sexes, as in the case of the use for crop support, differences arise in the type of crops supported.

Rights to plants provide another layer of complexity that was teased out in focus group discussions. Women don't need permission to gather fallen twigs or branches from figs located anywhere in the landscape with the exception of sacred groves. Anyone can harvest fallen twigs or leaves from common lands outside of sacred groves, but nonhousehold members wishing to harvest these from others' homegardens for subsistence use need permission and then women can only give permission to harvest from homegarden trees that they themselves have planted, unless the leaves are for medicinal purposes. Men do not require permission to harvest trees or parts of trees on their land even when women have planted them: "I don't have to get my wife's consent . . the tree is mine because it is on my land" (Mr. Amatte, $48 \mathrm{yrs})$.

When men have planted figs in any of the resource areas, women need their permission to use them to support other plants since men are very careful not to allow climbers that may damage the bark. However, women may use figs that they themselves have planted in their homegardens to support climbers, without their husbands' permission. Nor do women need permission to harvest crops supported by figs that men have planted if they already obtained permission to use them for crop support. While 
men can give anyone permission to harvest from figs that women have planted, they cannot give permission to harvest from women's plants that are supported by the figs.

Only men can give permission to others to hang beehives on their trees. Usually, the tree owner sets a limit to the number of hives that can be hung. If he has hung hives himself, then he usually allows only one other person to hang not more than two hives in the same tree. An average-sized fig tree can be used to hang up to six hives. No permission is usually sought to hang hives on figs that are located on common lands. Hive hanging is regarded as a non-destructive use, but great care must be exercised during honey harvesting not to damage the tree, especially if harvesting involves fire.

The right to harvest fig tree products therefore depends on land and tree ownership, on one's relationship to the owner, on the gender-identification of the resource area in which the tree is located (crop lands, homegardens, sacred groves), on who plants the figs, and on the use to which the product is put. The only right that does not vary according to resource area and use is that of male tree owners to harvest bark cloth - the only use that involves cutting parts of the tree - and then only from land that they legally own or occupy.

\section{ARTOCARPUS HETEROPHYLLUS (JACKFRUIT) (YAKOBO/FENE).}

Jackfruit is a non-indigenous multipurpose tree species that provides shade and support for vines such as passion fruit as well as a good source of firewood and highvalue timber. It produces one of the world's largest fruits which villagers consume fresh and sometimes sell. The fruit increases food security especially during periods of food shortage, when often only one hot meal a day is served and the mid-day meal consists of 
jackfruit. Villagers consider jackfruit as muzadde ("like a mother") because of its importance to food security. As one woman said, "Owning jackfruit trees is like having food in the granary."

In the study area, the predominant uses of jackfruit are for human fruit consumption (26 percent) and fuelwood (23 percent). Only men periodically cut branches for fuel which they sell or give to women for home consumption, and only men cut smaller branches to make handles for agricultural tools. Only men use jackfruits to support other plants and only men sell the fruit. However, less than 30 percent of the sampled households sell fruit, and these sell less than 20 percent of their yearly harvest. Men are involved in harvesting fuelwood and fruit for subsistence. Only women use the leaves for fodder, as a medicine to prevent prenatal illness and to wash their hands to remove sap after peeling green banana. The fruits are eaten, some are sold in local markets, and seeds are eaten after roasting. The fruit rind is fed to cattle and pigs.

Jackfruits mainly occur in homegardens (43 percent) and crop lands (32 percent), while some occur on common lands (9 percent) and in State forests (15 percent). Every household has at least one jackfruit, and on average four, but wealthier households have up to 30 trees. The harvest/use pattern, when considering all uses, generally closely conforms to tree distribution across the different resource areas, with a few exceptions. Although the majority of the trees occur in homegardens, harvesting fruit for sale occurs only in crop lands, and harvesting for fodder, medicine and soap occurs only in homegardens. Jackfruits on common lands and State forests are used only for subsistence fuelwood. Men reported over 80 percent of the uses of jackfruits on crop lands, whereas women reported 60 percent of the uses in homegardens, and only women reported 
gathering fallen branches in the State forest, since by law only women are allowed to do this. Jackfruits located in the different resource areas are used differently by men and women. However, even where the locations and uses are similar, such as for fruit and fuelwood, the purpose of use is distinct: men harvest for both sale and subsistence, while women harvest only for subsistence.

It was noted from group discussions that, because only men can make decisions to cut a tree or its limbs, wives require permission to harvest fuelwood if this involves cutting part of the tree, even when it is meant for domestic use. Further, men or boys harvest the fruit since it is socially unacceptable for women to climb trees. This originates from the time when women wore only cloth wrapped around their waists and chests, without undergarments. Also, a woman was considered to be ugly if she bore many scars, and tree-climbing can cut the skin. However, for small trees, climbing may not be necessary and therefore especially girls cut ripe fruit from smaller trees.

Customary rights to jackfruit are subject to a species- and product-specific regime. It is probably the importance of jackfruit to food security that ensures that rights to harvest for own consumption are not restricted to tree owners and their households. Tree owners' close relatives and friends receive some fruit after harvest on a reciprocal basis - the owner is obliged to give away the perishable fruit, which ensures that it is not wasted and households whose trees are not in fruit are assured of a supply. Since the trees fruit at different times depending on the age of the trees, there can be fruit yearround. "Food not shared is no food to be proud of. For others to know that you had a good yield, you must share what you produce. It is through sharing that you receive in return and the more you share the more you are respected by others" (woman, 50 years). 
However, for everyone irrespective of their relation to the tree owner, permission must be obtained to harvest fruit for sale. Non-household members obtain permission from women to harvest fruit from homegardens for on-site consumption or to take away if quantities are small, but women rarely give permission to non-household members to harvest fruit on crop lands, where it is men who must give permission. Even with permission, non-household members can only take away "a little" - not more than one fruit. Harvest frequency depends on how closely related the harvester is to the tree owner, where most respondents reported that kin may be allowed to harvest up to once every two weeks whereas non-kin may harvest only once a season.

\section{PHOENIX RECLINATA (PALM TREE) (KINSANSA/LUKOMA)}

Although trees in general are associated with male privilege, Phoenix reclinata is one of the tree species most strongly associated with women. Palm trees are used as a source of raw material for construction, furniture, crafts and to make fish traps. Their leaves are used for mat-making which is culturally important for women in Buganda. Women must sit on mats that they themselves make, as should the other members of their households, and women give these crafts as gifts and exchange them with relatives and friends - this is how their "leisure" time is spent. Traditionally, women never sold the crafts they made since this meant that their husbands were unable to meet household needs, which undermined men's social position. However, increasingly, Bugandan women are selling palm-based crafts in local markets.

Use of Phoenix reclinata is therefore highly gender-differentiated. Only women reported using it for broom-making and crafts, whereas only men use it for construction, 
fence posts, and to make fish traps. Crafts material constituted 42 percent of the total reported uses, including for mat- and basket-making, whereas construction constituted 26 percent, which mainly includes poles for latrines, leaf fronds for mud houses, and leaves for latrine doors. The male-only use of palms for construction is related to men's obligation to provide shelter for their households. Traditionally, any man who was involved in craft-making for household use was despised: men were obliged only to make bark cloth and only men who had no fig trees (usually the very poor and unskilled) made other crafts. In spite of prohibitions on women's commercial activities, women said that they must generate income because their husbands' income doesn't fulfill all household needs and, even when men manage to do this, they provide no money for women's "personal needs" such as clothing and cosmetics. In addition, some men from "poor" households harvest palm leaves to sell to women craft-makers, and some women contract poor men to harvest leaves in exchange for food. Even so, no one reported that men were involved in mat- or basket-making from palms - this would mean overstepping a firm gender boundary.

Palms occur mainly in State forest reserves (70 percent) and on common lands (28 percent), where their natural habitats are found, while very few occur in homegardens (2 percent). The use/harvest pattern closely conforms to this species distribution. Use patterns by resource area and sex are also simple to describe: men harvest from palms only in State forest reserves and reported 43 percent of total uses, whereas women reported more than half of the uses in State forest reserves and all of the uses on common lands, where the latter constitute 25 percent of the reported uses for craft materials. 
Both formal and informal rights govern the exploitation of palms on common land and in State forest reserves. Formally, women do not need permission to harvest palms in State forest reserves since regulations give women free access to non-timber forest products for subsistence purposes. But this is changing since the number of men involved in palm harvesting for commercial use is increasing, and the Forest Department has begun to restrict these activities since the species is listed as protected (Omagor 1999). With continued reclamation of wetlands for agriculture, palms are becoming increasingly scarce. Still, only men must seek permission to harvest palm since the Forest Department believes that only they harvest palms for commercial use. Despite this, men said that they never seek permission. But women are quite involved in commercial transactions for products made from palm leaves.

Informal rights to palms are governed principally by spiritual beliefs that affect the use of forest products generally and of palm in particular. For example, it is thought that spirits will "take over" the soul of anyone harvesting more than a single forest product at a time, and the harvester will never return home. Women are not allowed to enter the forest when it is dark since this is when forest spirits are active. If women encounter them, the spirits will render them infertile. Young palms are believed to harbor wetlands spirits that leave the palms when the leaves mature. The leaves are ready for harvest when maggot-like insects emerge from the leaf stalk, which indicates that the spirits have left. If the leaves are harvested before this, it is believed that the crafts made from them do not last, since the spirits were not allowed to leave the plant. Since the palm harbors spirits that protect wetlands, they also need to be protected, and anyone who 
cuts a palm will be "swallowed" by the wetland. The fear of spirits means that women harvest palm leaves in groups. However, men are not afraid and harvest individually.

\section{CLEOME GYNANDRA (CAT’S WHISKERS) (JOBYO).}

Cat's whiskers is the non-tree species selected for study: it is a tropical leafy vegetable that grows wild and is also cultivated which is widely used as a relish. As well as having insecticidal and repellant properties, it is highly nutritious (Chweya and Mnzava 1997). It is perishable and low-yielding, and in some areas is regarded as a weed. Cat's whiskers withstands dry seasons, although at a reduced growth rate (Rubaihayo 1992), thus providing households with food supplements during food-scarce periods.

In Buganda, the production of "minor" food crops such as leafy green vegetables is a woman's responsibility. Most of the non-tree plants cultivated in homegardens are thought of as "women's crops" as they are regarded to be "small" plants meant only for domestic consumption. Women consider Cat's whiskers as one of the most important food supplements in the study villages. They mostly mix it with other local vegetables and serve it as a side dish, or sometimes chop it and add it to other mixtures such as groundnut paste and serve it as a main relish. They also reported that Cat's whiskers has medicinal properties: the leaves are believed to cure headaches, stomach aches and uterine pains, aid childbirth, heal eye and skin infections, and counter malnutrition. The leaves are steamed together with another herb and ingested to treat high blood pressure; regular consumption is also believed to prevent malaria. The respondents were very hesitant to provide details about the concoctions and the ailments they cure as they regard 
that knowledge to be secret. Two women reported that they plant the vegetable near their cattle kraals to repel ticks. Women reported using Cleome sp only for subsistence, whereas men only earn income from the vegetable, which they harvest wild and sell through women and children. The involvement of men in vegetable harvesting, which is socially defined as a female activity, reflects increasing diversification of men's incomegenerating activities.

Cleome sp. was found to mainly occur in scattered spots within homegardens ( 0.55 percent per ha) and in State forests ( 0.33 percent $)$. Common lands contained only a 0.12 percent cover. ${ }^{8}$ Only one respondent was found to have the vegetable growing in his crop land and he regarded it as a weed. Generally the harvest pattern, when considering all uses, closely follows the distribution of Cleome sp., but there were a few exceptions. All harvesting for sale occurs in State forest reserves despite the prohibition on harvesting for sale. All men harvest only from the State forest reserve, while women harvest from all of the resource areas, although predominantly from homegardens. Harvesting for medicinal purposes was carried out in all resource areas. Women said that plants harvested from the forest are more effective for medicinal purposes than those harvested from homegardens, and those harvested from the "wild" forest and common lands are bitterer tasting.

Regarding rights to Cat's whiskers, everyone requires permission from women homegarden managers to harvest from their homegardens. It is a "crime" and a “disgrace" for any woman to be caught "stealing" vegetables from another's homegarden.

\footnotetext{
${ }^{8}$ From a plant density survey of randomly selected plots carried out in each location (see Nabanoga 2005).
} 
Usually the female head of household is in charge of harvesting vegetables, often accompanied by girls, which is how girls learn about production and harvesting. Girls younger than 15 are thought to have destructive harvesting practices and therefore normally do not harvest.

The discussion of customary rights to Cleome sp. revealed more general patterns around rights to plant resources per se that in principle are different from rights to trees. Women's homegardens are regarded as their private property and anyone wanting to harvest for any use from what is not their property is expected to obtain permission. There are, however, notable exceptions. For instance, elderly women can harvest vegetables for own consumption from any homegarden in the village. When asked why there are no restrictions on these women's rights, Mrs. Katumba (38 years), said "We get all our vegetable seed from the elderly women, therefore all vegetables belong to them. They even have the power to curse vegetable yields if you don't let them harvest."9 Closely-related kin are allowed to harvest enough vegetables to consume at one meal without permission as long as this does not become routine. Also, if a request for a vegetable is made by others than kin, the woman homegardener would have to harvest the vegetable for the requesting person. It was said that anyone could harvest a handful of the vegetable from another's garden as long as the vegetable is meant to feed a sick person, since it is then seen as a medication and not a food. No one can sell what is harvested from others' gardens.

\footnotetext{
${ }^{9}$ It is not at all unusual for older women, or women experts (e.g. homegardeners, plant breeders) to play such a role as providers of planting material. (See Howard 2003 and Howard, forthcoming)
} 
It is against social norms and therefore disgraceful for men to harvest vegetables. Unlike the case with trees, even male heads of households do not have the right to harvest vegetables from their wives' homegardens for any use other than for medicine. Single men have to rely on their female relatives to harvest vegetables. However, commercialization is changing these norms, in that it was reported that men have started to cultivate Cat's whiskers for sale, but these men give the harvest to children and women to sell at the roadside, and receive the income generated. The case of Cleome sp. shows that the right to harvest plants depends not only on the ownership and control of the resource area, but also on one's relationship to the plants' owners, the use to which the product is put, and the resource area in which the product is located.

\section{SPECIES OVERVIEW AND DISCUSSION.}

Figure 2 presents an overview of the uses of all four species by sex and resource area. Considering all uses of all selected plant species, it is apparent that both men and women use all resource areas although in different magnitudes. Most uses are related to private homegardens and crop lands, fewer are related to common lands, and the fewest were reported for State forests. Most of women's uses occur in homegardens where women are also the predominant users (68 percent of all homegarden uses reported) while most of men's uses occur in both crop lands (where men predominate with 92 percent of all uses) and homegardens - men use homegardens more than women use crop lands. Both men and women nearly equally use species found on common land while men predominate species' uses in State forests (62 percent). Looking at use alone, it could be argued that homegardens tend to be women's domains whereas crop lands are 
clearly men's, and non-private land is less clearly gendered. However, there are several complicating factors that must be considered.

Figure 2--Uses, resource areas and sex of users

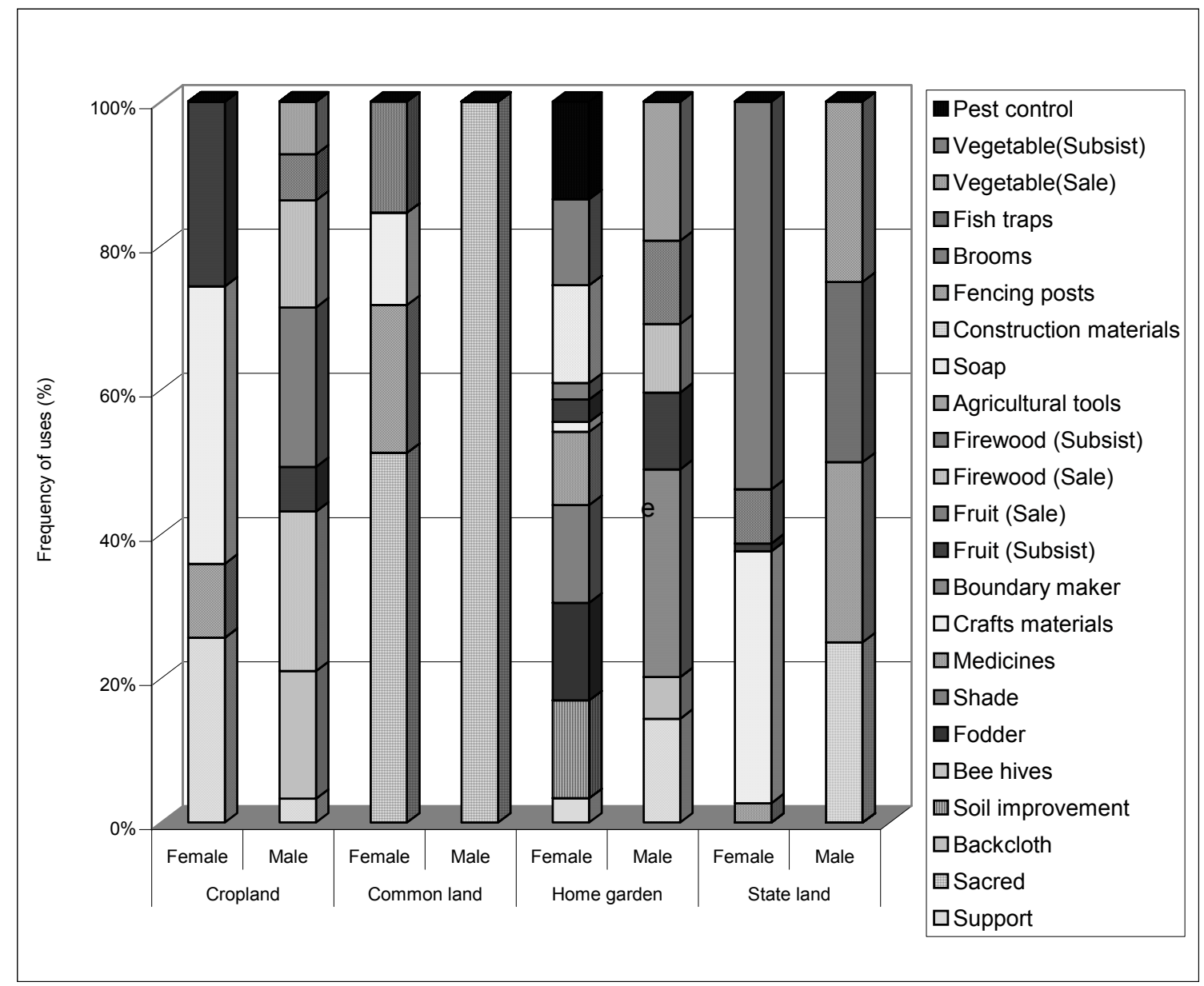


Figure 3--Uses by resource area and sex

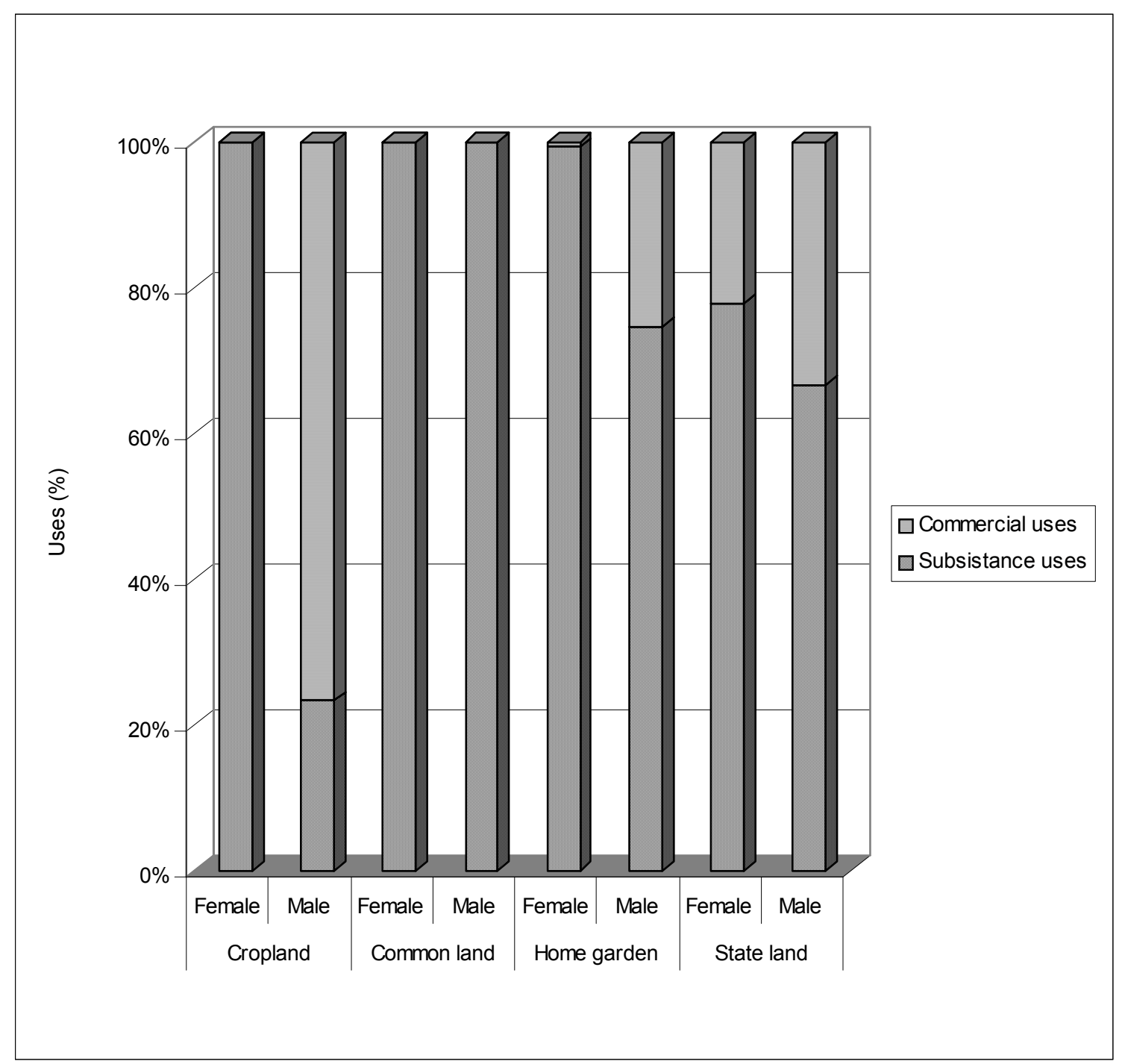

One of these complicating factors is commercial versus subsistence use. The sexdisaggregated use of species for subsistence or for sale across the various resource areas is presented in Figure 3. All of the uses made of the selected species found on common lands were for subsistence, and women's uses in both homegardens and crop lands were all for subsistence. Women only generate income from palms procured from State forests. 
In contrast, over 80 percent of men's uses in crop lands were income-generating, and men also earn income from homegardens and have more income-generating uses than women in State forests, although the latter is strictly prohibited. Income-generating uses were thus very male-dominated.

Males are very clearly the owners of trees growing on private land. On such land, all uses that entail cutting part or all of a tree (such as bark stripping or cutting branches for fuel or timber) are male, and all income generating uses of trees are male uses. Only palms represent an exception, since women cut palms and also generate income from palm products, but palms occur 98 percent on common lands or in State forests. ${ }^{10}$

It is clear that, although customary law grants men stronger legal rights to private land and trees compared to women, the informal system of rights that parallels such regimes recognizes women's rights to specific spaces, species, products and uses although women are certainly not as privileged as men. The difference between plant and tree rights is substantiated by respondents' comments regarding women's rights to non-tree species (e.g., plants that are supported by trees, other "minor crops" or vegetables) that are not mediated by men. Such subsistence botanicals that are not seen as "major" crops are predominantly described as belonging to women. It is only in relation to the tree species that women's rights are quite circumscribed - women can plant trees only with permission, can never cut trees or parts of trees, and can harvest from trees only for subsistence purposes and generally only with men's permission. Women apparently

\footnotetext{
${ }^{10}$ Unfortunately it is not possible to determine to what extent male tree tenure may predominate on common lands since, first, no distinction was made during this research between land that was under mailo tenure but used commonly, and land that is in customary communal tenure, and respondents were also not asked whether they sought permission from mailo owners to use trees on such land. Nevertheless, it is obvious that trees are cut on some communal lands, particularly palms.
} 
have the greatest rights to plants growing in their "own" spaces - homegardens - and the fewest rights in "men's spaces" - crop lands. With respect to the intersection between these variables - private ownership, usufruct rights to spaces, and rights to trees and plants - men have greater rights with respect to "women's spaces" than women have with respect to "men's spaces," since men have strong rights over the trees growing in women's spaces. However, men are very circumscribed when it comes to non-tree resources that women plant in homegardens, where they, like everyone else, require permission from women to harvest.

It has been argued that women often depend more on common land resources since these have no strong associated rights regime. But we have argued that 'common' resources are in fact not so 'common'. In fact it appears that women's rights to certain plant resources on common land are less circumscribed in comparison, for example, with their rights to these resources on men's crop land. However, another factor limits women's use of common land resources, since Bagandan cosmology clearly discriminates against women's access to sacred groves, but it is also clear that men's uses of tree and plant resources in sacred groves is also circumscribed. With respect to the State forest reserve, formal tenure appears to have little effect on local people's behavior with respect to the species that were investigated, and rather it is cultural norms and cosmology that tend to determine which people have which rights to which forest products. The State de jure presumes a traditional gender division of rights and obligations with respect to plant and tree products and privileges women's access to products from forest reserves since it is assumed that they use them only for subsistence purposes. But both men and women use forest products for subsistence and for income 
generation, and yet fears about spirits that tend to restrict "excessive" exploitation seem to restrict women's plant harvesting more than they restricts men's.

Rights to plants are also evident in social obligations of reciprocity, neighborliness and friendship that are often based in part upon gender, but that also depend on other "social identities" such as age. Harvesting for subsistence purposes is much less restricted irrespective of species and spaces, bearing out the proposition that plant rights regimes tend to ensure access to subsistence resources for all community members. The two general principles relating to harvesting for own consumption are that non-owners must generally seek permission from owners and may not cut or otherwise damage trees, and those who are closely related to the owners have more liberal access (receive a larger share of the product). Those who are not related by kin or household membership nevertheless have claims that are exerted as a function of reciprocity and neighborliness, as seen in the case of elderly women vegetable seed providers and of jackfruit. Medicinal plant use provides an exception to these principles - everyone has the right to harvest anywhere they occur without seeking permission. In contrast, permission would generally not be granted (nor, perhaps, even sought) to harvest plants or plant products growing on private land for commercial purposes: such rights are restricted to the owner, while other commercial harvesting occurs in State forest reserves or in communal land areas. The respondents reported that there was no enforcement of these rules, but everybody relies on others to respect them. None of the respondents reported that a situation had ever arisen that would imply a need to enforce the rules; everybody seemed to agree that there is social conformance with the norms. 
On the whole, then, it appears that, with the exception of rights to trees on private land and use of such trees for commercial purposes, and considering social definitions of gendered "spaces," women's customary rights to plant resources are at least as strong as men's, which can only be seen when considering plant rights as something potentially distinct from tree rights. Nevertheless, customary rights to plants among the Buganda are neither static nor wholly 'tradition-bound'. Change processes, including resource depletion, male out-migration, increasing formal education among children, increasing needs for cash, and changing cosmological beliefs are all affecting notions about what is appropriate behavior for women and men. Plant rights are still embedded in social norms and belief systems that reinforce the idea that women are about subsistence production, using "minor" resources and performing lower-status tasks, and men are about income generation, using "major" resources and performing higher-status tasks. Such ideologies are changing as is evident, for example in level of exploitation to which specific species such as palm are currently subjected. Women's commercial activities, once frowned upon as undermining their husbands' status, are now bolstered by male palm leaf harvesters, and husbands tolerate their wives' income generating activities, apparently as long as these do not involve the use of plant resources found on their own property. Where it was once believed that it is beneath a man's dignity to be seen harvesting vegetables, men are now involved in both harvesting and sales of 'women's crops'. Crossing genderboundaries still bears much social stigma, but it also occurs with increasing regularity. 


\section{CONCLUSIONS}

The case study presented here confirms the propositions put forward with respect to the existence of a traditional right regimes that regulates plant resource exploitation, where "tree tenure" and "plant tenure" are both evident and closely related, although distinguishable. It reveals the multidimensionality, nestedness and layered nature of rights to plants that are revealed when plotting land and tree tenure, spaces, species and

species use, as well as social identities of rights holders (by sex, age, household membership, kinship, etc.) on the same social and geographical map. It demonstrates that such a system establishes bundles of powers and obligations for heterogeneous groups of users and creates differential entitlements to benefits that are related to social structure.

The proposition that we put forth that, like plant knowledge, "bundles of powers" conform closely to "bundles of obligations," was born out in this research: social identities, including sex, age, household membership, and kinship clearly play important roles in defining who has which rights and obligations. In this, gender was the "social identity" that was most closely investigated. The results show that women and men have obligations to provide different subsistence and cultural resources and that men have obligations to provide cash. Beyond this, there are other duties with respect to generosity and reciprocity that are strongest among kin but still present among non-kin, and particularly with respect to people with specific social identities, i.e. children and older women 'vegetable seed providers'. These obligations are bundled with powers to access, manipulate, and dispose of closely associated plant resources. Social powers and obligations are as well infused with understandings and beliefs about the interpenetration 
of the spirit, human and natural worlds that understandably strike more fear into the hearts of women than into the hearts of men, and affect both apparently more than State forest rangers are able. Landscape and plant resources are much more than material phenomena - their cosmological meaning is also a gendered construct that privileges men and women differently and that tends to reinforce the definition of rights and obligations around plants - perhaps this is one reason that there appears to be little need for overt enforcement of social sanctions. These beliefs and rights with respect to plants and their associations with social identities represent one side of the equation, while formal property rights represent the other - both sides are gendered and embedded in relations of power, privilege and 'tradition'.

We have argued that the failure to recognize local rights regimes around plant resources poses clear dangers. Failing to recognize a thing does not in itself pose a threat - in fact it may be the best protection possible, as for example Dove (1990) argued in relation to plant resources in Javanese homegardens - their very invisibility as agroforestry systems that provide numerous local resources in small quantities throughout the year and that imitate surrounding landscapes made them difficult for both Dutch colonial powers and a centralized Indonesian state to expropriate, tax and disrupt. Feminists have made similar arguments about the 'invisibility' of resources that women control. However, the current debates around common property resources and Intellectual Property Rights to plant genetic resources, and the ensuing reconfiguration of international and national policies and laws, have become tangible forces that have no less significance for traditional plant rights regimes than colonialist land regimes had for traditional land use and land rights systems. 
It has been clear for decades that women's customary access to land and other natural resources have often been disrupted or transformed wholesale by the imposition of Western or other more patriarchal formal rights systems. ${ }^{11}$ In the process, women's formal as well as informal rights to control and even access a wide range of land-based resources have eroded. Such change has often been provoked by planned external interventions including legal land reforms in agriculture, forest and wildlife protection and conservation programs and laws, and reform of water laws and institutions and water infrastructure development. Many such changes have been unintended - intentional changes would presuppose that women's customary rights to such resources were recognized in the first place, which would be the exception rather than the rule. Gray and Kevane (1999) discuss the dilemmas currently confronted when seeking to redress women's eroding land tenure claims in Africa. Many advocate that current rights systems should be left alone - rather than attempting to formalize tenure relations, local institutions should be allowed to evolve undisturbed. However, active intervention will often be required to counteract the erosion that is occurring due to the phenomena mentioned earlier, and due to the challenges posed by the formal rights that are already in place. On the other hand, piecemeal interventions intended to remedy women's eroding land rights have often inadvertently contributed to this erosion.

Loss of plant biodiversity ensues as traditional and indigenous rights regimes break down since these have regulated access to and management of plant resources in

\footnotetext{
${ }^{11}$ See, for example, Agarwal (1994), Deere and Leon (2001) and Gray and Kevane (1999). Gray and Kevane conclude from their literature review: "Under formal titling women are dually condemned; land is no longer available through customary channels and women are severely restricted in their financial and social ability to gain land through government or market routes" (Gray and Kevane: 24).
} 
part to ensure continuing availability of such resources and the management of their respective environments (see e.g. Aagesen 1998; Acharya 1990; Aggarwal 2001; Bakhit and Hayati 1995; Chapeskie 1993; Cunningham 2001; Fondoun and Manga 2000; Irvine 1987; Lu 1999; Nelson 2003; Robbins 1996; Yeh 2000). Several of these studies attest to the positive welfare implications of such rights regimes since they are also oriented toward ensuring equitable access at least to subsistence resources, and of the deterioration in welfare (particularly food security, health and income) of the respective populations as plant rights regimes fail, and they also attest to the concomitant erosion in traditional botanical knowledge. Securing traditional plant rights is clearly only part of the solution - the driving forces cited in the introduction to this article clearly need to be addressed, but the neglect to even recognize existing plant rights regimes in Intellectual Property Rights and Common Property Rights discussions and debates practically ensures that they will fuel these negative trends.

The situation is perhaps even more difficult in relation to women - in spite of increasing recognition of and attempts to improve women's access to land and water resources, the likelihood that women's rights to plants will be considered in any policy forum is currently quite low. The only reference in any of the official documents related to the Convention on Biological Diversity to women's rights to plants is stated weakly as "strengthen their access to biological diversity" (UNEP 2000). This implies that women's customary access is currently weak, which is probably not the case in many societies - but it is likely to weaken. Such new regimes, for example, even when 'progressively' construed, are likely to assign IPR rights and benefits generated by globally-marketed medicinal plant resources to groups of male Shamans who are 
appointed to represent the 'community' of healers when these are mainly women herbalists, midwives and lay healer-housewives. Women's customary rights to manage landraces and seed resources are likely to erode as new varieties are provided to male farmers through research and extension, or as men are appointed 'custodians' of landraces that principally women have bred to meet culinary and ritual needs. Establishing tree plantations and enclosing land for environmental regeneration or wildlife protection often occurs taking men's interests at least minimally into account since they are members of formal local institutions, while women's customary rights to plant resources in these areas are simply ignored and usurped. ${ }^{12}$ IPR and CPR debates and their de jure and de facto outcomes cannot be considered as gender neutral since, due both to gender bias and to willful or unwitting ignorance of traditional and indigenous peoples' plant rights regimes, women are likely to be the last to benefit from such schemes, and in fact the most likely to be harmed.

\footnotetext{
${ }^{12}$ All of these phenomena have been reported to us by colleagues working in project contexts within the United Nations system - the first two examples come from South America, and the last from Ethiopia, Pakistan and Nicaragua.
} 


\section{REFERENCES}

Aagesen, D. L. 1998. Indigenous resource rights and conservation of the monkey-puzzle tree Araucaria araucana, Araucariaceae: A case study from southern Chile. Economic Botany 522: 146-160.

Acharya, H. P. 1990. Processes of forest and pasture management in a Jirel community of highland Nepal. PhD Dissertation, Cornell University. Ann Arbor, Michigan: University Microfilms International.

Agarwal, B. 1994. A field of one's own. gender and land rights in South Asia. Cambridge: Cambridge University Press.

Aggarwal, S. 2001. Supernatural sanctions in commons management: Panchayat forest conservation in the central Himalayas India. . PhD Dissertation, University of Hawaii. Ann Arbor, Michigan: University Microfilms International.

Akoroda, M. O. 1990. Ethnobotany of Telfairia occidentalis Cucurbitaceae among Igbos of Nigeria. Economic Botany 441: 29-39.

Bakhit, A. H., and O. Hayati. 1995. The Hadendowa Salif: Successes and failures of indigenous cultural institutions in managing the food system. Geojournal 361: 8792.

Berry, S. 1997. Tomatoes, land and hearsay: Property and history in Asante in the time of structural adjustment. World Development 258: 1225-1241.

Biggelaar, C. D. 1995. When a woman is a man: Inter- and intra-gender differences in tree tenure and planting in Rwanda. Agroforestry Today 7: 13-15.

Boster, J. S. 1985. Selection for perceptual distinctiveness: Evidence from Aguaruna cultivars of Manihot esculenta. Economic Botany 393: 310-325.

Boster, J. S. 1986. Requiem for the omniscient informant: There's life in the old girl yet. In Directions in cognitive anthropology, ed. Dougherty, J. Champaign, Ill: University of Illinois Press.

Bruce, J., and L. Fortmann. 1988. Why land tenure and tree tenure matter: Some fuel for thought. In Whose trees? Proprietary dimensions of forestry, ed. Fortmann, L. and J. W. Bruce. Boulder and London: Westview Press.

Calamia, M. A. 2003. Expressions of customary marine tenure and environmental entitlements: A case study involving common property regimes in a Fijian Outer island group. PhD Dissertation, University of Colorado. Ann Arbor, Michigan: University Microfilms International. 
CBD Convention on Biological Diversity. Secretariat. 1992. Convention on biological diversity. Montreal: CBD Secretariat. http://www.biodiv.org.

Chapeskie, A. 1993. Laws of the land: Aboriginal customary law, state law and sustainable resource management in Canada's North. PhD Dissertation, University of Ottawa Canada. Ann Arbor, Mich.: University Microfilms International.

Chweya, J. A. and N.A. Mnzava. 1997. Cat's whiskers, Cleome gynandra L. Promoting the conservation and use of underutilized and neglected crops no. 11. Rome: International Board for Plant Genetic Resources IPGRI. .

Cleveland, D. and S. Murray. 1997. The world's crop genetic resources and the rights of indigenous farmers. Current Anthropology 384: 477-515.

Compton, B. 1993. Upper north Wakashan and southern Tsimshian ethnobotany: The knowledge and usage of plants among the Oweekeno, Hanaksiala Kitlope and Kemano: Haisla Kitamaat. and Kitasoo Peoples of the Central and North Coasts of British Colombia. PhD Dissertation, University of British Columbia, Victoria. Ann Arbor, Michigan: University Microfilms International.

Conklin, H. C. 1954. The relation of Hanunoo culture to the plant world. $\mathrm{PhD}$ Dissertation, Yale University, New Haven, Conn.

Cunningham, A. B. 2001. Applied ethnobotany: People, wild plant use and conservation. London: Earthscan.

Deere, C. D., and M. Leon. 2001. Empowering women: Land and property rights in Latin America. Pittsburgh: University of Pittsburgh Press.

Descola, P. 1994. In the society of nature: A native ecology in Amazonia. Cambridge: Cambridge University Press.

Dick Bissonnette, L. 2003. The basket makers of the Central California Interior. In Women and plants: gender relations in biodiversity management and conservation, ed. P. Howard London and New York: Zed Press and Palgrave Macmillan.

Dove, M. R. 1997. Comment. Current Anthropology 384: p. 498.

Dove, M. R. 1990. Socio-political aspects of home gardens in Java: Review article. Journal of Southeast Asian Studies 211: 155-163.

Ellen, R. F. 1982. Environment, subsistence and system. The ecology of small-scale social formations. London: Cambridge University Press. 
Ellen, R. F. 1993. Rhetoric, practice and incentive in the face of the changing times: A case study in Nuaulu attitudes to conservation and deforestation. In Environmentalism: The view from anthropology, ed. Milton, K. London and New York: Routledge.

Ellen, R. F. 1998. Indigenous knowledge of the rainforest: Perception, extraction and conservation. In Destruction and development of the tropical rainforest, ed. Maloney, B. Dordrecht: Kluwer.

Eyzaguirre, P. and E. Dennis. 2006. The impacts of collective action and property rights on plant genetic resources. World Development. Forthcoming.

FAO (Food and Agriculture Organization of the United Nations). 2004. Report of the Second International Workshop and Steering Committee Meeting, GloballyImportant Ingenious Agricultural Heritage Systems GIAHS. Project, June 7-9, Rome, Italy. Online at: ftp://ftp.fao.org/agl/agll/giahs/Report_SC2_GIAHS_041005.pdf.

Fondoun, J. M., and T.T. Manga. 2000. Farmers' indigenous practices for conserving Garcinia kola and Gnetum africanum in southern Cameroon. Agroforestry Systems 483: 289-302.

Fortmann, L. and J.W. Bruce. 1988. Whose trees? Proprietary dimensions of forestry. Boulder and London: Westview Press.

Fortmann, L. and Rocheleau, D. 1985. Women and agroforestry: Four myths and three case studies. Agroforestry Systems 24: 253-272.

Fortmann, L., C. Antinori, and N. Nabane. 1997. Fruits of their labors: gender, property rights, and tree panting in two Zimbabwe villages. Rural Sociology 623: 295-314.

Goebel, A. 2003. Gender and entitlements in the Zimbabwean woodlands: A case study of resettlement. In Women and plants: Gender relations in biodiversity management and conservation, ed. Howard, P. London and New York: Zed Press and Palgrave-Macmillan.

Gombya-Ssembajjwe, W., and A.Y. Banana. 1998. Property rights and sustainability of forests in Uganda. Paper presented at 'Crossing Boundaries,' the Seventh Annual Conference of the International Association for the Study of Common Property, Vancouver, British Columbia, Canada, June 10-14.

Gray, L., and M. Kevane. 1999. Diminished access, diverted exclusion: Women and land tenure in Sub-Saharan Africa. African Studies Review 422: 15-39.

Grigsby, W. J. 2002. Subsistence and land tenure in the Sahel. Agriculture and Human Values 192: 151-164. 
Howard, P. 2003. Women and the plant world: An exploration. In Women and plants: Gender relations in biodiversity management and conservation, ed. Howard, $\mathrm{P}$. London and New York: Zed Press and Palgrave-Macmillan.

Howard, P. 2006. The social structure of tropical homegardens: What gender dynamics reveal. In Tropical homegardens, ed. Kumar, B. and P. Nair. Berlin, Germany: Springer Science. Forthcoming.

Howe, J., and J. Sherzer. 1975. Take and tell: A practical classification from the San Blas Cuna. American Ethnologist 23: 435-460.

Irvine, D. 1987. Resource management by the Runa Indians of the Ecuadorian Amazon. PhD Dissertation, Stanford University. Ann Arbor, Michigan: University Microfilms International.

IWMI (International Water Management Institute), University of Greenwich, University of Dar-es-Salaam, and South African Department of Water Affairs and Forestry. 2005. Proceedings of African Water Laws: Plural Legislative Frameworks for Rural Water Management in Africa. January 26-28 2005. Johannesburg, South Africa. Papers published online at: http://www.nri.org/waterlaw/workshop.htm.

Kabuye, C. Ed. 1999. Bark cloth in Buganda. London: Intermediate Technology Publications and UNEP.

Katende, A. B., A. Birnie, and B. Tengnäs. 1995. Useful trees and shrubs for Uganda: Identification, propagation and management for agricultural and pastoral communities. Nairobi: Regional Soil Conservation Unit, Swedish International Development Authority SIDA.

Kundhlande, G. and M. Luckert. 1998. Towards an analytical framework for assessing property rights to natural resources: A case study in the communal areas of Zimbabwe. Staff Paper 98-05, Dept. of Rural Economy. Edmonton, Canada: University of Alberta.

Leach, M. 1992. Women's crops in women's spaces. Gender relations in Mende rice farming. In Bush base: Forest farm. culture, environment and development, ed. Croll, E. and D. Parkin. London: Routledge.

Lu, F. E-Shen 1999. Changes in subsistence patterns and resource use of the Huaorani Indians in the Ecuadorian Amazon. PhD Dissertation, University of North Carolina at Chapel Hill. Ann Arbor: University Microfilms International.

Malm, T. 1999. Shell age economics: Marine gathering in the kingdom of Tonga, Polynesia. PhD Dissertation, Lunds University Sweden. 
McDermott, M. 2000. Boundaries and Pathways: Indigenous Identity, Ancestral Domain, and Forest Use in Palawan, the Philippines. PhD Dissertation, University of California Berkeley. Ann Arbor, Michigan: University Microfilms International.

Mgbeoji, I. C. M. 2002. Patents and plants: Rethinking the role of international law in relation to the appropriation of traditional knowledge of the uses of plants TKUP. JSD, Dalhousie University Canada. Ann Arbor, Michigan: University Microfilms International.

Millennium Ecosystem Assessment 2005. Millennium Ecosystem Assessment synthesis report. Pre-publication Final Draft Approved by MA Board on March 3. http://www.millenniumassessment.org//en/Products.Synthesis.aspx.

Mukwaya, A. B. 1953. Land tenure in Buganda: Present day tendencies. Kampala, Uganda: The Eagle Press.

Nabanoga, G. 2005. Transgressing boundaries: Gendered spaces, species, and indigenous forest management in Uganda. Tropical Resources Management Papers No. 60. Wageningen, The Netherlands: Wageningen University and Research Centre.

Nagujja, Z. 1993. A review of laws and decided cases on the law of succession. A report prepared for the Ministry of Women in Development, Culture and Youth. Kampala, Uganda.

Nelson, M. 2003. Forestry and cultural sustainability in the Little Red River Cree Nation Alberta. Masters Thesis, University of Alberta Canada. . Ann Arbor, Michigan: University Microfilms International.

Norton, H. H. 1985. Women and resources of the Northwest Coast: Documentation from the 18th and early 19th centuries. PhD Dissertation, University of Washington. Ann Arbor, Michigan: University Microfilms International.

Nugent, D. 1993. Property relations, production relations, and inequality: Anthropology, political economy, and the Blackfeet. American Ethnologist 202: 336-362.

O'Flaherty, M. 1997. Managing a Commons: Community management of indigenous woodlands in Chimanimani District, Zimbabwe. PhD Dissertation, University of Toronto. Ann Arbor, Michigan: University Microfilms International.

Oguamanam, C. V. 2003. International Law, plant biodiversity and the protection of indigenous knowledge: An examination of intellectual property rights in relation to traditional medicine. Thesis, Faculty of Law, University of British Columbia. Ann Arbor, Michigan: University Microfilms International. 
Olson, M. 1995. The spirits of Vaoto: Changing political authority, ideology, and environmental practice in Samoa. PhD Dissertation, University of California, Berkeley. Ann Arbor, Michigan: University Microfilms International.

Omagor, N. 1999. Swamp forest plant resources in Uganda: Their uses and conservation challenges. International Tree Crops Journal 10: 107-120.

Padmanabhan, M. 2006. The making and unmaking of gendered crops in Northern Ghana. Singapore Journal of Tropical Geography. Forthcoming.

Peluso, N. 1996. Fruit trees and family trees in an anthropogenic forest: Ethics of access, property zones, and environmental change in Indonesia. Comparative Studies in Society and History 383: 510-548.

Pfeiffer, J. and Butz, R. 2005. . The relevance of gender to ethnobiological research. Journal of Ethnobiology 252. .

Pottier, J. 1999. Anthropology of food. The social dynamics of food security. Cambridge: Polity Press.

Price, L. 2003. Farm women's rights and roles in wild plant food gathering and management in North-East Thailand. In Women and plants: gender relations in biodiversity management and conservation, ed. P. Howard London and New York: Zed Press and Palgrave Macmillan.

Quisumbing, A. R. 1995. Gender differences in agricultural productivity: A survey of empirical evidence. Food Consumption and Nutrition Division Discussion Paper No. 5. Washington DC: International Food Policy Research Institute.

Quisumbing, A. R., Otsuka, K., Suyanto, S., and Aidoo, J. B. 2001. Land, trees, and women: Evolution of land tenure institutions in Western Ghana and Sumatra. Washington DC: International Food Policy Research Institute.

Ray, B. C. 1977. Sacred spaces and royal shrines in Buganda. History of Religions, 164: 363-373.

Ribot, J. C., and Peluso, N. 2003. A theory of access. Rural Sociology, 682: 153-181.

Robbins, P. 1996. Negotiating ecology: Institutional and Environmental Change in Rajasthan, India. PhD Dissertation, Clark University. Ann Arbor, Michigan: University Microfilms International.

Rocheleau, D. 1988. Women, trees, and tenure: Implications for agroforestry. In Whose trees? Proprietary dimensions of forestry. Boulder, Colorado: Westview Press.

Rocheleau, D., and Edmunds, D. 1997. Women, men and trees: Gender, power and property in forest and agrarian landscapes. World Development 258: 1351-1371. 
Roquas, E. 2002. Stacked law. Land, Property and Conflict in Honduras. Amsterdam: Rozenberg Publishers Thela Latin America Series. .

Roscoe, J. 1965. The Baganda: An Account of their Native Customs and Beliefs. London: Frank Cass and Co., Ltd.

Rubaihayo, E. B. 1992. The diversity and potential use of local vegetables in Uganda. In First national plant genetic resources workshop: Conservation and utilisation, November 9-11, Mukono Uganda:.

Scott, J. C. 1976. The moral economy of the peasant: Rebellion and subsistence in Southeast Asia. New Haven, Conn: Yale University Press.

Sebina-Zziwa, A. J. 1998. The paradox of tradition: Gender, land and inheritance rights among the Baganda. PhD Dissertation, University of Copenhagen.

Sheridan, M. 2001. Cooling the land: The political ecology of the North Pare Mountains, Tanzania. PhD Dissertation, Boston University. Ann Arbor, Michigan: University Microfilms International.

Sillitoe, P. 2003. The gender of crops in the Papua New Guinea Highlands. In Women and plants: gender relations in biodiversity management and conservation, ed. $\mathrm{P}$. Howard London and New York: Zed Press and Palgrave Macmillan.

UNEP United Nations Environment Program. . 2000. Report of the Working Group on the Implementation of Article 8j. and Related Provisions, Conference of the Parties to the Convention on Biological Diversity, Fifth meeting, May 15-26 2000, Nairobi. Item 11 of the provisional agenda, UNEP/CBD/COP/5/5, 12 April.

Wagner, J. 2002. Commons in transition: An analysis of social and ecological change in a coastal rainforest environment in rural Papua New Guinea. $\mathrm{PhD}$ Dissertation, McGill University Canada. . Ann Arbor, Michigan: University Microfilms International.

Warner, K. 1993. Patterns of farmer tree growing in Eastern Africa: A Socio-economic Analysis. Tropical Forestry Papers No. 27. Nairobi: ICRAF and Oxford: Oxford Forestry Institute.

Yeh, E. T. 2000. Forest claims, conflicts and commodification: The political ecology of Tibetan mushroom-harvesting villages in Yunnan Province, China. China Quarterly, 161: 264-278. 
List of CAPRi Working Papers

01 Property Rights, Collective Action and Technologies for Natural Resource Management: A Conceptual Framework, by Anna Knox, Ruth Meinzen-Dick, and Peter Hazell, October 1998.

02 Assessing the Relationships Between Property Rights and Technology Adoption in Smallholder Agriculture: A Review of Issues and Empirical Methods, by Frank Place and Brent Swallow, April 2000.

03 Impact of Land Tenure and Socioeconomic Factors on Mountain Terrace Maintenance in Yemen, by A. Aw-Hassan, M. Alsanabani and A. Bamatraf, July 2000 .

04 Land Tenurial Systems and the Adoption of a Mucuna Planted Fallow in the Derived Savannas of West Africa, by Victor M. Manyong and Victorin A. Houndékon, July 2000.

05 Collective Action in Space: Assessing How Collective Action Varies Across an African Landscape, by Brent M. Swallow, Justine Wangila, Woudyalew Mulatu, Onyango Okello, and Nancy McCarthy, July 2000.

06 Land Tenure and the Adoption of Agricultural Technology in Haiti, by Glenn R. Smucker, T. Anderson White, and Michael Bannister, October 2000.

07 Collective Action in Ant Control, by Helle Munk Ravnborg, Ana Milena de la Cruz, María Del Pilar Guerrero, and Olaf Westermann, October 2000.

08 CAPRi Technical Workshop on Watershed Management Institutions: A Summary Paper, by Anna Knox and Subodh Gupta, October 2000.

09 The Role of Tenure in the Management of Trees at the Community Level: Theoretical and Empirical Analyses from Uganda and Malawi, by Frank Place and Keijiro Otsuka November 2000.

10 Collective Action and the Intensification of Cattle-Feeding Techniques a Village Case Study in Kenya's Coast Province, by Kimberly Swallow, November 2000.

11 Collective Action, Property Rights, and Devolution of Natural Resource Management: Exchange of Knowledge and Implications for Policy, by Anna Knox and Ruth Meinzen-Dick, January 2001. 
12 Land Dispute Resolution in Mozambique: Evidence and Institutions of Agroforestry Technology Adoption, by John Unruh, January 2001.

13 Between Market Failure, Policy Failure, and "Community Failure": Property Rights, Crop-Livestock Conflicts and the Adoption of Sustainable Land Use Practices in the Dry Area of Sri Lanka, by Regina Birner and Hasantha Gunaweera, March 2001.

14 Land Inheritance and Schooling in Matrilineal Societies: Evidence from Sumatra, by Agnes Quisumbing and Keijuro Otsuka, May 2001.

15 Tribes, State, and Technology Adoption in Arid Land Management, Syria, by Rae, J, Arab, G., Nordblom, T., Jani, K., and Gintzburger, G., June 2001.

16 The Effects of Scales, Flows, and Filters on Property Rights and Collective Action in Watershed Management, by Brent M. Swallow, Dennis P. Garrity, and Meine van Noordwijk, July 2001.

17 Evaluating Watershed Management Projects, by John Kerr and Kimberly Chung, August 2001.

18 Rethinking Rehabilitation: Socio-Ecology of Tanks and Water Harvesting in Rajasthan, North-West India, by Tushaar Shah and K.V.Raju, September 2001.

19 User Participation in Watershed Management and Research, by Nancy Johnson, Helle Munk Ravnborg, Olaf Westermann, and Kirsten Probst, September 2001.

20 Collective Action for Water Harvesting Irrigation in the Lerman-Chapala Basin, Mexico, by Christopher A. Scott and Paul Silva-Ochoa, October 2001.

21 Land Redistribution, Tenure Insecurity, and Intensity of Production: A Study of Farm Households in Southern Ethiopia, by Stein Holden and Hailu Yohannes, October 2001.

22 Legal Pluralism and Dynamic Property Rights, by Ruth Meinzen-Dick and Rajendra Pradhan, January 2002.

23 International Conference on Policy and Institutional Options for the Management of Rangelands in Dry Areas, by Tidiane Ngaido, Nancy McCarthy, and Monica Di Gregorio, January 2002. 
24 Climatic Variablity and Cooperation in Rangeland Management: A Case Study From Niger, by Nancy McCarthy and Jean-Paul Vanderlinden, September 2002.

25 Assessing the Factors Underlying the Differences in Group Performance: Methodological Issues and Empirical Findings from the Highlands of Central Kenya, by Frank Place, Gatarwa Kariuki, Justine Wangila, Patti Kristjanson, Adolf Makauki, and Jessica Ndubi, November 2002.

26 The Importance of Social Capital in Colombian Rural Agro-Enterprises, by Nancy Johnson, Ruth Suarez, and Mark Lundy, November 2002.

27 Cooperation, Collective Action and Natural Resources Management in Burkina Faso: A Methodological Note, by Nancy McCarthy, Céline Dutilly-Diané, and Boureima Drabo, December 2002.

28 Understanding, Measuring and Utilizing Social Capital: Clarifying Concepts and Presenting a Field Application from India, by Anirudh Krishna, January 2003.

29 In Pursuit Of Comparable Concepts and Data, about Collective Action, by Amy Poteete And Elinor Ostrom, March 2003.

30 Methods of Consensus Building for Community Based Fisheries Management in Bangladesh and the Mekong Delta, by Parvin Sultana and Paul Thompson, May 2003.

31 Formal and Informal Systems in Support of Farmer Management of Agrobiodiversity: Some Policy Challenges to Consolidate Lessons Learned, by Marie Byström, March 2004.

32 What Do People Bring Into the Game: Experiments in the Field About Cooperation in the Commons, by Juan-Camilo Cárdenas and Elinor Ostrom, June 2004.

33 Methods for Studying Collective Action in Rural Development, by Ruth Meinzen-Dick, Monica Di Gregorio, and Nancy McCarthy, July 2004.

34 The Relationship between Collective Action and Intensification of Livestock Production: The Case of Northeastern Burkina Faso, by Nancy McCarthy, August 2004.

35 The Transformation of Property Rights in Kenya's Maasailand: Triggers and Motivations by Esther Mwangi, January 2005. 
36 Farmers' Rights and Protection of Traditional Agricultural Knowledge, by Stephen B. Brush, January 2005.

37 Between Conservationism, Eco-Populism and Developmentalism - Discourses in Biodiversity Policy in Thailand and Indonesia, by Heidi Wittmer and Regina Birner, January 2005.

38 Collective Action for the Conservation of On-Farm Genetic Diversity in a Center of Crop Diversity: An Assessment of the Role of Traditional Farmers' Networks, by Lone B. Badstue, Mauricio R. Bellon, Julien Berthaud, Alejandro Ramírez, Dagoberto Flores, Xóchitl Juárez, and Fabiola Ramírez, May 2005.

39 Institutional Innovations Towards Gender Equity in Agrobiodiversity Management: Collective Action in Kerala, South India, by Martina Aruna Padmanabhan, June 2005.

40 The Voracious Appetites of Public versus Private Property: A View of Intellectual Property and Biodiversity from Legal Pluralism, by Melanie G. Wiber, July 2005.

41 Who Knows, Who Cares? Determinants of Enactment, Awareness and Compliance with Community Natural Resource Management Bylaws in Uganda, by Ephraim Nkonya, John Pender, Edward Kato, Samuel Mugarura, and James Muwonge, August 2005.

42 Localizing Demand and Supply of Environmental Services: Interactions with Property Rights, Collective Action and the Welfare of the Poor, by Brent Swallow, Ruth Meinzen-Dick, and Meine von Noordjwik, September 2005.

43 Initiatives for Rural Development through Collective Action: The Case of Household Participation in Group Activities in the Highlands of Central Kenya, By Gatarwa Kariuki and Frank Place, September 2005. 